\title{
Sheldon Wolin's (In)Vocations: Dichotomies, Paradoxes, and the Mystery of Politics
}

\section{In memoriam}

\author{
Facundo Vega ${ }^{1}$ \\ Cornell University, New York (Estados Unidos)
}

Recibido: 17-04-16

Aprobado: 06-09-16

Sheldon Wolin, one of the most influential contemporary political theorists, died in 2015 at the age of 93. His remarkable legacy within political thought includes written works such as Politics and Vision and lives on as well in a variety of his former students, for instance, Cornel West and Wendy Brown. Wolin's intellectual heritage is sure to persist, given that he "lived in the presence of time past, time present, and time future" 2 .This brief essay, however, does not seek an obituary tone ${ }^{3}$. Rather, I will comment on particular topics inherent to Wolin's

${ }^{1}$ (fhv3@cornell.edu). Facundo Vega is a Ph.D. candidate at Cornell University as well as a visiting scholar in the Institut für Philosophie at the Freie Universität Berlin and the Johann Wolfgang GoetheUniversität Frankfurt am Main.

This essay owes a great deal to conversations with Étienne Balibar, Bruno Bosteels, Wendy Brown, Jason Frank, Carlos Forment, Andreas Kalyvas, Diego Rossello, and Geoff Waite. I am also deeply indebted to Janet Hendrickson for her valuable comments on an earlier draft. Finally, I am grateful to the Deutscher Akademischer Austauschdienst (DAAD) and the Rosa-Luxemburg-Stiftung for financial support.

${ }^{2}$ Norton, Anne, "In Memory of Sheldon Wolin (1922-2015)" in Boston Review, November 2, 2015, N/A: https://bostonreview.net/blog/sheldon-wolin-ann-norton

3 See, among others: Hedges, Chris, "Sheldon Wolin and Inverted Totalitarianism," in Truthdig. Drilling Beneath the Headlines, November 1, 2015, N/A: http:/www.truthdig.com/report/item/ sheldon_wolin_and_inverted_totalitarianism_20151101; Norton, Anne, op. cit.; Robin, Corey, "The Theorist Who Reached Across Time," in Jacobin, October 24, 2015, N/A: https://www.jacobinmag. com/2015/10/wolin-politics-and-vision-berkeley-machiavelli-democracy/; Kreitner, Richard, "Sheldon Wolin, 1922-2015," in The Nation, October 30, 2015, N/A: http://www.thenation.com/ article/sheldon-wolin-1922-2015/; Grimes, William, "Sheldon S. Wolin, 93, Dies; Political Theorist Saw Limits of Popular Democracy," in The New York Times, October 28, 2015, N/A: http://www. nytimes.com/2015/10/29/us/politics/sheldon-s-wolin-theorist-who-shifted-political-science-back-topolitics-dies-at-93.html. See, also: Markell, Patchen, "Unexpected Paths: On Political Theory and 
interpretation of democracy by taking into consideration Bonnie Honig's twofold rendition of it, centered on the paradoxical character of politics. The political paradox, understood as the ineradicable impossibility of identifying or producing the general will within politics, expresses the limitations of any essentialism, permeating every moment of political life -even beyond the event of new regimes' founding ${ }^{4}$. Put differently, the paradox of politics is a rubric to name the ineluctable uncertainty inherent in democratic legitimacy. Honig distinguishes her understanding of the paradox of politics from the comprehension of paradoxes in deliberative or decisionist perspectives. For her, the potentiality of the paradox of politics is lodged in its attentiveness to the contestatory character of life-in-common. More specifically, she assumes that, insofar as the paradox of politics is animated by a plural way of dealing with the question of political origins and foundations, this paradox helps us criticize the imposition of binaries sustained in the form of "either-or". In sum, according to Honig's interpretation of the political paradox, "the people are always also a multitude, the general will is inhabited by the will of all, the law(giver) is possibly a charlatan, and political theorists' objectivity is also partisan"s. In this light, Honig conceives Wolin, on the one hand, as a democratic theorist attentive to the paradoxical status of political life, given that, for him, political foundation "is not the opening chapter in a $[B]$ ildungsroman, but a pivotal moment in a tragic story of [...] theft", and, under this aegis, for him, "a democratic tradition built on practices now lost would be very different from the one we have" ${ }^{\text {. }}$. On the other hand, Honig asserts that Wolin insists "on democracy's need for a slower and less plural tempo than that characteristic of our [...] late modern world"; that is, in a certain way, he limits the space of the political paradox. My reflections in this essay remain attentive to this

History" in Theory \& Event, Vol. 19, Issue 1, 2016, N/A; Marcus, David, "Into the Cave: Sheldon Wolin's Search for Democracy," in Dissent, Vol. 63, No. 1, Winter 2016, pp. 98-108.

${ }^{4}$ On the political paradox, see, among others: Canovan, Margaret, The People, (Cambridge: Polity, 2005); Connolly, William, Identity|Difference: Democratic Negotiations of Political Paradox, (Ithaca: Cornell University Press, 1991), The Ethos of Pluralization (Minneapolis: University of Minnesota Press, 1995); Honig, Bonnie, Democracy and the Foreigner, (Princeton, N.J.: Princeton University Press, 2001), "Between Decision and Deliberation: Political Paradox in Democratic Theory" in American Political Science Review, Vol. 101, No. 1, (2007), pp. 1-17; Keenan, Alan, Democracy in Question. Democratic Openness in a Time of Political Closure, (Stanford, California: Stanford University Press, 2003); Mouffe, Chantal, The Democratic Paradox, (London: Verso, 2000); Näsström, Sofia, "The Legitimacy of the People" in Political Theory, Vol. 35, No. 5, (October 2007), 624-658; Rancière, Jacques, La mésentente. Politique et philosophie (Paris, Éditions Galilée, 1995). English translation by: Julie Rose, Disagreement. Politics and Philosophy (Minneapolis: University of Minnesota Press, 1998); Ricoeur, Paul, "Le Paradoxe Politique," in Histoire et Vérité, (Paris: Éditions du Seuil, 1964), pp. 260-284. English translation by: Charles A. Kelbley, "The Political Paradox" in History and Truth, (Evanston: Northwestern University Press, 1965), pp. 247-270. See also: Connolly, William (ed.), Legitimacy and the State (New York: New York University Press, 1984), pp. 250-272.

5 Honig, Bonnie, "Between Decision and Deliberation: Political Paradox in Democratic Theory," in The American Political Science Review, Vol. 101, No. 1, (Feb., 2007), p. 14.

${ }^{6}$ Honig, Bonnie, Emergency Politics. Paradox, Law, Democracy, (Princeton: Princeton University Press, 2009), pp. 34-35.

${ }^{7}$ Ibid., p. 50.

Araucaria. Revista Iberoamericana de Filosofia, Política y Humanidades, año 18, no 36. Segundo semestre de 2016. Pp. 485-496. ISSN 1575-6823 e-ISSN 2340-2199 doi: 10.12795/araucaria.2016.i36.21 
twofold status of Wolin's theoretical enterprise that Honig detects: if one aspect of his vision is receptive to the unstable, contentious, and contingent character of democracy, another precludes the work of de-essentialization within the political realm by imposing rigid analytical dichotomies - for instance, between the body politic and political economy, revolution and constitution, or democracy and form - to understand it. Firstly, I will summarize the particular inflection that democracy acquires in Wolin's work. In stark contrast to theories that hypostatize democracy and reinforce its condition of mere political regime -that is, a set of norms, forms, or procedures- Wolin emphasizes its temporal and experiential character, one that is condensed in his notion of "fugitive democracy". It is in this vein that Wolin affirms: "[D]emocracy is a political moment, perhaps the political moment, when the political is remembered and recreated". As a temporal experience, democracy remains discordant and unstable and is -or better, was and should be- (fugitively) instantiated by participation and voice. As is evident, Wolin's conception of democracy attempts to avoid essentialism, both in form and substance. Secondly, I will evaluate whether Wolin's theory accomplishes those challenges and desiderata regarding political essentialism by considering some critical remarks on Wolin's vision of democracy provided by contemporary political theorists. In this light, I will show how the persistence of dichotomies is part and parcel of Wolin's approach. My concern is whether such dichotomies in general can convincingly navigate the dilemmas of democracy, that is, of an experience based on ungrounded groundings, in which "political events and dramas exceed [...] hypostatized categorizations".

\section{Paradoxical Visions of Democratic Politics}

In his seminal work Politics and Vision, Wolin elucidates why political theory cannot be comprehended as the deployment of an essence or an eternal nature of things. Rather, for Wolin, political theory should be understood as dealing with the plural meaning of political practice. This contingent character of politics opens up the space for the emergence of a paradox insofar as, according to Wolin, "politics is both a source of conflict and a mode of activity that seeks to resolve conflicts and promote readjustment"10. This incongruity, however, does

${ }^{8}$ Wolin, Sheldon, "Norm and Form: The Constitutionalizing of Democracy" in Athenian Political Thought and the Reconstruction of American Democracy, J. Peter Euben, John Wallach, and Josiah Ober (eds.) (Ithaca: Cornell University Press, 1994), p. 55; and "Fugitive Democracy," in Democracy and Difference: Contesting the Boundaries of the Political, Benhabib, Seyla (ed.) (Princeton: Princeton University press, 1996), p. 43. (Emphasis in the original).

${ }^{9}$ Honig, Bonnie, "Between Decision and Deliberation: Political Paradox in Democratic Theory" in op. cit., p.14.

${ }_{10}$ Wolin, Sheldon, Politics and Vision. Continuity and Innovation in Western Political Thought, (Boston: Little, Brown and Company, 1960), p. 11.

Araucaria. Revista Iberoamericana de Filosofía, Política y Humanidades, año 18, n 36. Segundo semestre de 2016. Pp. 485-496. ISSN 1575-6823 e-ISSN 2340-2199 doi: 10.12795/araucaria.2016.i36.21 
not belong to the political experience merely as an object of observation. To put it succinctly, it is political theory itself that enacts a paradoxical status, given that it implies a vision that is at the same time an act of description and an act of imagination, a reference to and beyond the empirical domain ${ }^{11}$. In virtue of this double attribute, one could argue that Politics and Vision advocates not only for a politics, but also for a political theory, that escapes the institutionalization and description of a status quo that precludes political contentiousness. Consequently, Wolin condemns the "penchant of modern political thought for converting political problems into administrative ones" 12 . This tendency is epitomized in an age of normalization that, according to Wolin, entails the diffusion of "the political" at the hands of "constitutional theory [that] is both a variant of organizational theory and a political methodology"13. I will elaborate more on this issue later. In the meantime, it is worth noting that even though these theoretical developments belong to Wolin's magnum opus -which was published more than two decades before the articles I will discuss in this piece- they can help us perceive the manner in which he came to understand democracy later on by emphasizing its protean and fugitive character. More importantly, Politics and Vision might encourage us to ask whether the project of radical democracy needs to be based on pervasive antinomies.

Nicholas Xenos, Wolin's former student, is certainly aware of the role that antitheses play in Wolinian political thought. He states that it is possible to recognize two phases in Wolin's elucidation of the tension between democracy and form, a tension that itself configures one of the main examples of the use of radical contradictions to give an account of political life. During the first period, composed of texts published in the journal democracy, such as "The People's Two Bodies" or "What Revolutionary Action Means Today", as well as articles published in his collection The Presence of the Past, Wolin directly engages with the American experience. During the second period, comprising texts such as "Fugitive Democracy", "Norm and Form: The Constitutionalizing of Democracy", and "Transgression, Equality and Voice", Wolin focuses, according to Xenos, on the experience of Athens in the fifth and forth century $\mathrm{BCE}^{14}$. In general, to be sure, it is the democratic experience as a realm of instability, contention, and contingency that fuels Wolin's vision. What needs to be expressed here, however, is that for Wolin democracy as theoretical problem remains linked to a vital issue that lies beyond empirical constraints, insofar as the United States grounded its

11 Ibid., pp. 17-18.

12 Ibid., p. 314.

13 Ibid., p. 392. On Wolin's understanding of methodology, see: "Political Theory as a Vocation" in The American Political Science Review, Vol. 63, No. 4, (Dec., 1969), pp. 1062-1082.

${ }^{14}$ For a distinction regarding the two phases in Wolin's late approach to democracy, see: Xenos, Nicholas, "Momentary Democracy" in Democracy and Vision: Sheldon Wolin and the Vicissitudes of the Political, Botwinick, Aryeh and Connolly, William (eds.) (Princeton: Princeton University Press, 2001), pp. 25-38. 
collective existence on a model of power animated by an advanced economy which spread destructive effects: "The question", Wolin states, "is about political identity, about who we are as a people"15. Wolin addresses that question by resemantizing Ernst Kantorowicz's The King's Two Bodies. According to Wolin, the American political tradition is the territory for the emergence of two kinds of collectivities: one politically active and democratic, called a body politic; the other almost entirely passive, antidemocratic, and defined by political economy. The Declaration of Independence and the Revolution of 1776 are the chief symbols of one body; the Constitution, The Federalist Papers, and Hamilton's work in general are the salient motifs of the other. Put differently, American politics remains (in)animated by two bodies. While the first body "envisaged a being who would not just participate in politics, but would join in actually creating a new political identity, to 'institute', 'alter' or 'abolish' governments, to lay a 'foundation' and to organize power" 16 ; the second produced a reaction against democratic and participatory politics and hypostatized the meaning of political collectivity through the persistence of state and political economy ${ }^{17}$.

Critics have observed Wolin's tendency to consider "revolutionary people as wholly betrayed by the constitutional order, and persisting as an outside force" 18 . In this vein, revolution would seem to enact the energy of "the people," and its legal framework would amount to depoliticization. This essential opposition, however, fails to observe a situation of double inscription of "the people". In fact, despite what Wolin maintains, "it is not the constitutional people versus the revolutionary people [...] but the relation of tension by which each sustains the other" ${ }^{\prime \prime}$. This kind of argument re-positions the paradoxical status of politics, because "the people" remains simultaneously a constituted and a constituent power ${ }^{20}$. And a take on paradoxes, it is worth noting, might invite us to weaken Wolin's tendency to rely on rigid dichotomies.

From Wolin's vision, nonetheless, an exceptional situation would seem to be sufficient cause to draw upon theoretical binaries. In particular, constitutional political economy jeopardizes the tradition of revolutionary politics by imposing

15 Wolin, Sheldon, “The People's Two Bodies", in democracy 1, No. 1, (January 1981), p. 10.

${ }^{16}$ Ibid., p. 10. According to Wolin, "democracy means participation, but participation is not primarily about 'taking part,' as in elections or office holding. It means originating or initiating action with others". See: Wolin, Sheldon, The Presence of the Past. Essays on the State and the Constitution, (Baltimore: Johns Hopkins University Press, 1989), p. 150. See also: Frank, Jason, Constituent Moments. Enacting the People in Postrevolutionary America, (Durham: Duke University Press, 2010), p. 153.

17 Wolin, Sheldon, "The People's Two Bodies" in op. cit., p. 16.

${ }^{18}$ Frank, Jason, Constituent Moments. Enacting the People in Postrevolutionary America, op. cit., p. 30. Interestingly, Andreas Kalyvas states that "Sheldon Wolin's exaltation of an agonistic demos and a 'transgressive' democracy" is one of the chief disassociations of "the extraordinary from any reference to rules, procedures, or norms". See: Kalyvas, Andreas, Democracy and the Politics of the Extraordinary: Max Weber, Carl Schmitt, Hannah Arendt, (Cambridge, New York: Cambridge University Press, 2008), p. 5.

${ }^{19}$ Ibid., pp. 30-31. (Emphasis in the original).

${ }^{20}$ Ibid., p. 31. 
muteness. But it is precisely the task of elucidating "What Revolutionary Action Means Today" that faces the present silence, which "is a symptom of a crisis [whose] origins are in the one-sided conception of citizenship that was reflected in the Constitution" 21 and which spread a notion of "the citizen" as a mere bearer of rights. The difference between the citizens and the members of interest groups is of particular importance to Wolin. In his own words, "the citizen, unlike the groupie, has to acquire a perspective of commonality, to think integrally and comprehensively rather than exclusively. The groupie never gets beyond 'politics, 'the stage of unreflective self-interest" ${ }^{\prime 22}$. This claim for commonality, to be sure, can be conceived as yet another expression of Wolin's condemnation of politics as administration. As opposed to mere administrative processes, "the political", according to Wolin, relies on a participatory democracy whose main aim is to enact a fight against the oblivion of the revolution. It should be noted, nevertheless, that Wolin envisions revolution as the possibility of creating new political forms, or better, "[of reinventing] the forms and practices that will express a democratic conception of collective life"23. The corollary of this theoretical maneuver within the conception of revolutionary politics as a creative moment is that citizenship entails the capability of generating power beyond the state's paradigm.

Such an articulation of the state becomes crucial in Wolin's The Presence of the Past. In this work, new dichotomies organize his vision: namely, the opposition between tending and intending, unum and pluris, or contract and birthright. Basically, "tending inclines toward a democratic conception of political life [and] intending toward an authoritarian conception [which] loves the principle of authority, that is, the right to command and enforce obedience" ${ }^{24}$. As a result, the American tradition has actualized the hegemony of unum and, therefore, drowned the energy of pluris ${ }^{25}$. While the former tendency was imposed after the Constitution of 1787; the Revolution of 1776, according to Wolin, implied a feudal revolt against the centralization of power and helps us remember that "American history [...] is a story of differences. It is a history that suggests that the true archaism is unum with its myth of a single people and a single narrative. And perhaps the supreme archaism is unum's proudest

21 Wolin, Sheldon, "What Revolutionary Action Means Today," in Mouffe, Chantal (ed.), Dimensions of Radical Democracy: Citizenship, Community, (London: Verso, 1992), 240-253. [This article was first published in democracy 2, No. 4, (Fall 1982), pp. 17-28].

${ }^{22}$ Ibid., p. 245. (Emphasis added).

23 Ibid, p. 249.

${ }^{24}$ See: Wolin, Sheldon, The Presence of the Past. Essays on the State and the Constitution, op. cit., p. 88.

${ }_{25}$ In this vein, Wolin affirms that: "The conflict between unum and pluris took the form of rationality versus difference, between national power based upon what The Federalist called 'the new science of politics' and the 'imbecility' of the constitutional system embodied in decentralized systems". Ibid., p. 134.

Araucaria. Revista Iberoamericana de Filosofía, Política y Humanidades, año 18, n 36. Segundo semestre de 2016. Pp. 485-496. ISSN 1575-6823 e-ISSN 2340-2199 doi: 10.12795/araucaria.2016.i36.21 
achievement, the state"26. Finally, while birthright calls for politicalness and citizens as interpreters, contract theory prefigures a memoryless person and the imposition of political economy and state. At this stage, however, I would ask: does Wolin's reference to dichotomies do justice to his acute understanding of democracy as a dispute among plural meanings of political institution? Is it possible to establish a strict boundary between, for instance, the people's two bodies, constitution and revolution, tending and intending, unum and pluris, birthright and contract? Do those rigid dichotomies not preclude the acknowledgment of the very paradoxical status of politics?

It seems relevant to emphasize the prevalence of antitheses in a second set of Wolin's texts: "Norm and Form: The Constitutionalizing of Democracy", "Transgression, Equality and Voice", and "Fugitive Democracy". In the first of these essays, Wolin opposes constitution and revolution once again and asks: "[W]hen a democratic revolution leads to a constitution, does that mark the fulfillment of democracy, or the beginning of its attenuation?"27. Once more, Wolin considers that "constitutional democracy" implies the repression of democracy he sees at work in the legacy of Federalists ${ }^{28}$. Arguing against a history of political thought that indicates that democracy has collapsed because of its routinization, professionalization, and institutionalization, Wolin advocates a democracy understood as resistant to every form of rationalization and organization. In his words: "[I]nstead of a conception of democracy as indistinguishable from its constitution, I propose accepting the familiar charges that democracy is inherently unstable, inclined toward anarchy, and identified with revolution and using these traits as the basis for a different, aconstitutional conception of democracy"29. These ideas are inspired by the Greek experience of democracy as a politics of the demos ${ }^{30}$. The energy of that

${ }^{26}$ Ibid., p. 136. "For those who care about creating a democratic political life", Wolin emphasizes, "a strong state must be rejected because the idea of a democratic state is a contradiction in terms". See: Ibid., p. 149.

${ }^{27}$ Wolin, Sheldon, "Norm and Form: The Constitutionalizing of Democracy" in Athenian Political Thought and the Reconstruction of American Democracy, Euben, J. Peter, Wallach, John, and Ober, Josiah (eds.) (Ithaca: Cornell University Press, 1994), p. 30.

${ }^{28}$ By constitutionalism, Wolin means "the theory of how best to restrain the politics of democracy [...]". See: Wolin, Sheldon, "Norm and Form: The Constitutionalizing of Democracy" in op. cit., p. 35. On the impasses of constitutional democracy, see also: Brown, Wendy, "American Nightmare: Neoliberalism, Neoconservatism, and De-Democratization" in Political Theory, Vol. 34, No. 6, (December 2006), p. 696.

${ }^{29}$ See: Wolin, Sheldon, "Norm and Form: The Constitutionalizing of Democracy" in op. cit., p. 37. (The first emphasis is added, the second is in the original).

${ }^{30}$ By taking into consideration Athenian democracy, Wolin argues that "the great achievement of self-government was to transform politics in sight and speech; power was made visible; decision making was opened so that citizens could see its workings; ordinary men personified power, spoke to it unservilely, and held themselves answerable. The most crucial and revealing element in Athenian democracy was the system of annual rotation in office, the lot, and the public subsidization of citizen participation. Rotation and lot both function to limit the effects of institutionalization: they are, paradoxically, institutions that subvert institutionalization". See, Ibid., pp. 42-43. (Emphasis added).

Araucaria. Revista Iberoamericana de Filosofía, Política y Humanidades, año 18, n 36. Segundo semestre de 2016. Pp. 485-496. ISSN 1575-6823 e-ISSN 2340-2199 doi: 10.12795/araucaria.2016.i36.21 
kind of experience, however, was jeopardized by legalism, depersonalization, and objective normativity, which, in Wolin's view, formed the core of a project that he calls "the constitutionalizing of surplus democracy" 31 . The temperament of this project remains connected to the proliferation of the notion of "form" that limits the revolutionary and excessive experience of democracy ${ }^{32}$. Interestingly enough for Wolin, democracy as the politics of the demos cannot be apprehended by any regime or form of government, but dwells in time and memory and, therefore, needs to be remembered, recreated, and renewed.

The temporal and revolutionary conception of democratic politics that Wolin portrays and defends was fiercely limited by legal constraints. Through this contradiction, critics have also discussed Wolin's use of dichotomies to enervate the Hamiltonian myth of America as a state centered on constitution. According to Xenos, for instance, "by pitting the revolutionary against the constitutional images of America, Wolin is propagating one myth against another, with political intent" ${ }^{\prime 33}$. This type of "mystical fiction", which produces an elucidation of a political -and anti-politicalbody, however, can amount to a metaphysical consolation and a mythic form-giving. One additional problem lies in Xenos's perception of Wolin's essentialism, whose "emphasis upon commonality would sometimes seem to promote the Community over communities" ${ }^{34}$. This essentialist temptation is also evident, Xenos emphasizes, in Wolin's account of a political "renewal" that, paradoxically, is in tension with the momentary and transgressive status of democracy. That is, "to apply the term 'renewal' to the appearance of the political is to imply an essential nature to the political that it does not have in Wolin's conceptualization" ${ }^{35}$. In a nutshell, Xenos shows us not only the emergence of fixed dichotomies but also of allusions to natures and essences at work in Wolin's account of democracy.

Democratic life, Wolin emphasizes, can be housed but not realized either by constitution or by a mere electoral process. In "Transgression, Equality and Voice", particularly, he delineates a certain trajectory of democracy, taking as a modern starting point Spinoza's notion of "multitudo" understood as a new political actor based on the concept of conatus. By observing the ancient experience of democracy through this lens, Wolin sheds light on the transgressive impulse of the Many ${ }^{36}$. This tendency is accompanied by a new conception of politics. In a meaningful way, then, Wolin suggests that "transparent politics

\footnotetext{
${ }^{31}$ Ibid., p. 47.

${ }^{32}$ Wolin claims for the presence of "democracy [as] wayward, inchoate, unable to rule yet unwilling to be ruled. It does not naturally conform. It is inherently formless". See: Wolin, Sheldon, Ibid., p. 50. (Emphasis in the original).

${ }^{33}$ Xenos, Nicholas, "Momentary Democracy," op. cit., p. 28.

${ }^{34}$ Ibid., p. 33.

${ }^{35}$ Ibid., p. 34.

${ }^{36}$ Wolin, Sheldon, "Transgression, Equality and Voice" in Dēmokratia: A Conversation on Democracies, Ancient and Modern. Ober, Josiah and Hedrick, Charles (eds.), (Princeton: Princeton University Press, 1996), p. 79.
} 
was the corollary of the revolutionary principle of full popular participation or, more precisely, of freedom understood as truly popular participation" 37 . The experience of ancient democracy and its conatus-driven bias, instantiated by the practice of collective action, emerges as the counterpoint to the system that Wolin calls electoral democracy. More specifically, Wolinian democracy requires the existence of "the people" as an actor. Yet, "[f]or 'the people' to become an actor, not simply an elector, more than will [is] needed: a voice [is] also required"38. It is precisely this experience that Wolin observes in the expression vox populi, vox dei and that, according to him, is lacking in the recent American context - a context defined by "a democracy without the demos as actor [that is, one where] the voice is that of a ventriloquous democracy" 39 .

\section{The Promises of Demos and the Political Labyrinth}

Throughout this essay, I attempted to portray Wolin's elucidation of democracy and his quarrel with electoral politics vis-à-vis the prevalence of exclusive polarities within his work. The epitome of this gesture is evident in "Fugitive Democracy," a text in which it is possible to detect a new inflection of the praise for dichotomization that is at work in Wolin's intellectual project. If in previous instances the opposition between constitution and revolution catalyzed Wolin's understanding of democracy, in this case, the distinction between "politics" and "the political" animates his thematization of life-incommon. While the former refers to "legitimized and public contestation," the latter is connected to the emergence of moments of commonality and to the expression of the collective power ${ }^{40}$. "Politics", Wolin claims, "is continuous, ceaseless, and endless. In contrast, the political is episodic, rare" ${ }^{41}$ and, as such, it constitutes the raison d'être of his democratic project. The state, according to Wolin, prefigures a domestication of "the political" through the imposition of boundaries. Consequently, the development of a purely constitutional scheme establishes a "democracy without the demos as actor" ${ }^{2}$, which is to say, a demos without voice. In stark contrast to the implications of such a dictum, Wolin's democracy emerges from revolution and transgression of political forms. It follows from what has been said that "democracy is not about where the political is located but about how it is experienced"43. Revolution

\footnotetext{
${ }^{37}$ Ibid., p. 80.

${ }^{38}$ Ibid., p. 86.

39 Ibid., p. 87.

${ }^{40}$ Wolin, Sheldon, "Fugitive Democracy" in Benhabib, Seyla (ed.), Democracy and Difference, (Princeton: Princeton University Press, 1996), p. 31.

${ }^{41}$ Ibid., p. 31.

42 Ibid., p. 34.

43 Ibid., p. 38.
}

Araucaria. Revista Iberoamericana de Filosofia, Política y Humanidades, año 18, n 36. Segundo semestre de 2016. Pp. 485-496. ISSN 1575-6823 e-ISSN 2340-2199 doi: 10.12795/araucaria.2016.i36.21 
as an experience gives its energy and sparks of commonality to democracy. Institutionalization, regularization, and administration of "the political", by contrast, produce "the attenuation of democracy" 44 . In other words, democracy is devitalized by form and, as Wolin clarifies, becomes a fugitive moment. Its story is marked by its own disappearance, from the fall of Athens to the American and French revolutions. George Kateb takes into consideration this particular disposition of Wolin's project to assert that the Wolinian democratic moment has no creative power ${ }^{45}$, which is why he affirms that there is a Sorelian tone in Wolin's celebration of eruption for its own sake. According to Kateb, Wolin's "passion is a noble passion, noble as it is futile. It is Marx's passion, but because it is without Marx's hope, it becomes Sorelian. The democratic energies of creation are redirected to destruction" ${ }^{\prime 4}$. And yet, would it be fair to say that Wolin is a kind of nihilist without any further explanation? I think that one cannot simply answer "yes" insofar as "fugitive democracy" is always already a project $\dot{a}$ venir. My concern, however, takes the form of a question: can that project and its nuances be apprehended only by (and through) dichotomies? Could not those oppositions instantiate a Maginot Line that goes through all of our political history and precludes taking into account democracy as the territory of a dispute?

In contrast to Kateb, Fred Dallmayr takes Wolin's formulations on the fugitive character of democracy to open up a discussion on the transgressive or transformational inflection of postmodern democracy -informed by ontologyfor which he argues. As a critique of liberal-individualistic and republican collectivist models, Dallmayr delineates an understanding of democracy that rejects the constraints of the incarnation of sovereignty and collective identity. Under this aegis, he mentions Claude Lefort's distinction between "the political" and "politics", and specifies that "politics refers to overt, empirical political strategies while polity (or the political) denotes the constitutive, quasitranscendental matrix of political life; that is, the public space that allows for the mise-en-scène (or staging) of politics" ${ }^{\prime 4}$. This theoretical maneuver

\footnotetext{
${ }^{44}$ Ibid., p. 39.

${ }^{45}$ Kateb strongly criticizes Wolin's theorization of "fugitive democracy". In his view, the notion of "fugitive democracy" entails a "no exit" attitude, one that remains "a sudden eruption of democracy that is doomed to subside and to leave the prevailing structures, nominally but not truly democratic, intact". See: Kateb, George, "Wolin as a Critic of Democracy," in Democracy and Vision: Sheldon Wolin and the Vicissitudes of the Political, op. cit., p. 39.

46 Ibid., p. 56. A re-elaboration of this rendition should take into account Wolin's concern with the notion of "invocation". "While vocation implies action, a practice, invocation may be said to imply memory and to enjoin recovery. Vocation predicates a certain commitment, 'ideal' though not disinterested, to the particular practice in question. Invocation is a response to a certain kind of loss". See: Wolin, Sheldon, "Political Theory: From Vocation to Invocation," in Vocations of Political Theory, Frank, Jason and Tambornino, John (eds.), (Minneapolis: University of Minnesota Press, 2000), p. 5.

${ }^{47}$ Dallmayr, Fred, "Beyond Fugitive Democracy: Some Modern and Postmodern Reflections" in Democracy and Vision: Sheldon Wolin and the Vicissitudes of the Political, op. cit., p. 66.
} 
attempts to limit every enclosure, embodiment, and essentialization of lifein-common. Thus, Dallmayr states that in a "radical or modern/postmodern democracy $[\ldots]$ the 'people' invoked in popular self-government [...] is not a fixed or static identity but rather the emblem of human self-transformation and maturation, of the striving for self-rule that always remains a task and a challenge"48. What needs to be expressed here, however, is that on the one hand, Wolin would not support a project of postmodern democracy ${ }^{49}$. On the other hand, more importantly, it remains to be seen whether the productivity of ontology for understanding politics should be taken for granted ${ }^{50}$. The call for an ontological relevance of "the political", it is true, could enervate proceduralism's suppression of political contingency. The overstatement of "the political", nonetheless, could produce a new essentialism, one sustained by the repetition of the ontologically extra-ordinary until its own collapse ${ }^{51}$.

According to my reading, the imposition of binaries that intend to capture political exceptions can actually jeopardize the very meaning of the nonordinary, hypostatizing the political realm. An Aus-einander-setzung with this question demands recalling Wolin's most powerful lesson about radical politics: democracy is "a project concerned with the political potentialities of ordinary citizens, that is, with their possibilities for becoming political beings through the self-discovery of common concerns and of modes of action for realizing them" 52 . Wolin's vision might serve as an invitation to observe that revolution and constitution, democracy and form, the politically ordinary and extra-ordinary are not mutually exclusive; rather, each actually dwells in the folds of the other. More significantly perhaps, similar to the recovery of a lost treasure, Wolin's (in)vocations invite us to comprehend that politics cannot

${ }^{48}$ Ibid., p. 72.

49 "The pervasive presence of the state, the rise of technocratic elitism, the closely knit structure of state and corporate bureaucracies, and the decline of the ideology of egalitarianism in favor of a meritocracy," Wolin suggests, "are the signs of a postmodern politics in which democracy serves primarily a rhetorical function with little or no correlative in official institutions or practices". See: Wolin, Sheldon, The Presence of the Past. Essays on the State and the Constitution, op. cit., p. 81.

${ }^{50}$ See: Bosteels, Bruno, The Actuality of Communism, (London: Verso, 2011), pp. 42-74.

51 The entrenchment of "the political" associated with "the extraordinary" has a precedent in Friedrich Nietzsche's philosophy. See: Jaspers, Karl, Nietzsche. Einführung in das Verständnis seines Philosophierens, (Berlin und Leipzig: Verlag Walter de Gruyter \& Co., 1936), p. 224. English translation by: Charles F. Wallraff and Frederick J. Schmitz, Nietzsche. An Introduction to the Understanding of His Philosophical Activity, (Tucson: The University of Arizona Press, 1965), p. 251. Praise for "the political" is also evident in: Schmitt, Carl, Der Begriff des Politischen, (Berlin: Duncker \& Humblot,1932). English translation by: George Schwab, The Concept of the Political, (Chicago: The University of Chicago Press, 2007). Current repercussions of the difference between "politics" and "the political" are analyzed, among others, in: Marchart, Oliver, Post-Foundational Political Thought. Political Difference in Nancy, Lefort, Badiou and Laclau, (Edinburgh: Edinburgh University Press, 2007); Die politische Differenz. Zum Denken des Politischen bei Nancy, Lefort, Badiou, Laclau und Agamben, (Berlin: Suhrkamp Verlag, 2010).

${ }^{52}$ Wolin, Sheldon, "Fugitive Democracy" in op. cit., p. 31. See also: Keenan, Alan, Democracy in Question. Democratic Openness in a Time of Political Closure, op. cit., p. 7.

Araucaria. Revista Iberoamericana de Filosofía, Política y Humanidades, año 18, n 36. Segundo semestre de 2016. Pp. 485-496. ISSN 1575-6823 e-ISSN 2340-2199 doi: 10.12795/araucaria.2016.i36.21 
depend on the certainty of any form of organized domination. Politics, rather, resides within the mystery of the extra-ordinary and, more specifically, in its democratization -which is also, in part, a philosophico-political task ${ }^{53}$.

53 "[M] editative culture", according to Wolin, "nourishes all creativity. That culture is the source of the qualities crucial to theorizing: playfulness, concern, the juxtaposition of contraries, and astonishment at the variety and subtle interconnection of things". See: Wolin, Sheldon, "Political Theory as a Vocation," in op. cit., p. 1073. 